\title{
IMPROVING THE MILLING MACHINE COMPETENCY LEARNING OUTCOMES THROUGH INDUSTRIAL PROJECT-BASED LEARNING FOR VOCATIONAL SCHOOL STUDENTS
}

\author{
Heri Yudiono \\ Universitas Negeri Semarang \\ Wirawan Sumbodo \\ Universitas Negeri Semarang \\ Salim \\ Sekolah Menengah Kejuruan Negeri 1 Semarang \\ Rizki Setiadi \\ Universitas Negeri Semarang
}

\begin{abstract}
This research is motivated by the implementation of conventional learning. Besides, student learning motivation is still low due to student activities that are less centered on making workpieces that are suitable for work in the industry. Learning outcomes show that only 55.88\% of students reach Minimum Completeness Criteria (Kriteria Ketuntasan minimum or KKM). The design and learning of productive machining competencies that are in accordance with the needs of the industry influence students' experience and learning outcomes. This study aims to analyze the results of industrial project-based learning (InPro-BL) milling machine competency learning outcomes in SMK Negeri 1 Semarang. The method used in this study is Class Action Research (CAR) through four stages: (1) planning, (2) implementation of actions, (3) observation and evaluation, (4) reflection. The samples were 34 students of class XII of Mechanical Engineering. The data were collected using product assessment instruments to measure dimensional accuracy, timeliness, level of disability, level of smoothness, and work attitude. This study was descriptive quantitative, and qualitative. The results of the study show that InPro-BL is effective in improving the learning outcomes of milling machine competencies. In Cycle I, there is an increase in learning outcomes, from 19 students who completed the KKM to 25 students or $73.52 \%$. In Cycle II, there are $88.23 \%$ of students passed the KKM. These results can be improved by paying attention to the management of learning time through the block system, teacher's understanding of industrial-project-based learning, and industry guest teachers mentoring every learning process.
\end{abstract}

Keywords: learning outcomes, student experience, milling machine engineering, industrial projects

Permalink: $h t t p: / / d x . d o i . o r g / 10.21831 / j p v . v 9 i 2.23686$

Contact Heri Yudiono@heri_yudiono@mail.unnes.ac.id

Department of Mechanical Engineering, Universitas Negeri Semarang Jl. Taman Siswa Sekaran, Gunungpati Semarang, 50229 Jawa Tengah, Indonesia 


\section{INTRODUCTION}

Vocational schools, as a subsystem of vocational education, are expected to be able to shape innovative, creative, competitive, and sustainable characters requiring sociocultural and structural support. Vocational education has its own peculiarities in choosing substantive learning must always keep abreast of technology, community needs, individual needs, and job requirements (Yudiono, 2017). Global transformation towards a knowledge-based economy encourages increased demand for quality human development as a resource, international, and national competition (Cheng, 2005). Vocational education requires a conceptual framework that is proven in meeting objectives effectively, efficiently, and meaningfully. The pattern of the conceptual framework cultivates vocational values in vocational schools in each region that are different from each other because each region in Indonesia has unique sociocultural characteristics, different regional potentials, different local advantages, political and economic policies different.

Vocational school is a part of Indonesia's national education, which plays a strategic role in producing a competent national workforce that is globally competitive and promotes sustainable development. Vocational education must be pro-work, pro-activity, pro-growth, pro-distribution, and pro-prosperity. Vocational education significantly influences sustainable development. Therefore, learning content must meet the labor requirements (Yudiono, Soesanto, \& Haryono, 2018).

The transformation in the planned world of education must, of course, meet the principles of the principle of link and match, which is at the core of the successful implementation of vocational education. The application of this concept does not only massively trigger the transformation of educational facilities and infrastructure but also demands changes to the teacher as the main actor who carried out learning in school. The fact that happened in Indonesia as one of the developing countries is that it must face several obstacles to realize ideal vocational education based on the concept of link and match such as lack of qualified teachers, difficult to meet high operational costs, lack of equipment for practice, lack of curriculum clarity and maintenance problems and repair equipment (Bukit, 2014).
The success of learning in school will be realized from the success of students learning. Learning is a form of behavioral changes in a person expressed in new ways of behaving thanks to experience and practice (Hamalik, 1983). Student learning success also depends on student motivation. There are two types of motivation, intrinsic and extrinsic, which are based on the different reasons or goals that underlie an action. Intrinsic motivation refers to doing something because it is inherently interesting or fun, whereas extrinsic motivation refers to doing something because it leads to results that are fun but external and can be separated. Self-determined motivation is found to be associated with more interest, effort, positive emotions, satisfaction, and commitment by students (Ryan \& Deci, 2000).

SMK N 1 Semarang is one of the Vocational Schools in Semarang which has a Mechanical Engineering Skills Program. The standard of competence expected from graduates is to be able to do conventional machining work with a milling machine. In achieving these competency standards, students must be able to operate the milling machine in making products needed by the industry. The achievement of competency standards is done by using learning methods that are in accordance with the needs of the industry. One of the industrial partners owned by SMK N 1 Semarang is CV Surya Cipta Inti Pratama which produces spurs gears and bevel gears. Implementation of the existing industrial-based partnership management model of Vocational High Schools (VHS) on Mechanical Engineering expertise has only $62.5 \%$ ready to work graduates which belongs to low category (Sumbodo, Pardjono, Samsudi, \& Rahadjo, 2018).

The results of preliminary studies show that there are still many problems that arise in machining learning that have an impact on the development of student competencies as expected by industry partners. These problems relate to learning models that suit the needs of students and industry, the development of teacher competencies based on industry competency, the time of student practice learning, and the feasibility of practicum support equipment that is in accordance with the industry partners. In addition, the lack of a more comprehensive partnership between the school and the industry in aligning the curriculum, teacher apprenticeship, and sharing resources. 
Competency development will be efficient if the environment in which students are trained is a replica of the environment where they will later work (Prosser \& Allen, 1959). The development of graduate competencies also emphasizes practical knowledge and direct ability; some of them have the problemsolving experience, so teachers in vocational high schools have problems teaching students problem-solving (Chiang \& Lee, 2016). In order for vocational graduates to work under the industrial needs, then in the learning process, there is a need for learning as done by industry. The concept of production-based learning is a new paradigm, both academic and industrial learning. This learning aims to provide students with technical activities and practices directly under industrial conditions (Rentzos, Doukas, Mavrikios, Mourtzis, \& Chryssolouris, 2014). A very effective production-based learning model was developed in the learning of students in increasing creativity and innovation (Ganefri, 2013).

Competence is described as the capacity to carry out specific activities that will always require several combinations of knowledge skill/disposition/values which when it is analyzed, it almost always seems like a combination of generic or key competence (Gonczi, 2004). The theory of developing competencies emphasizes that students must not only acquire but also integrate knowledge, skills, and attitudes to achieve vocational competence (Kaslow et al., 2007). Based on the existing curriculum, the core competencies needed in the milling machine are shown in Table 1.

Table 1. Competencies Needed in Milling Machine.

\begin{tabular}{ll}
\hline \multicolumn{1}{c}{ Subject } & \multicolumn{1}{c}{ Competency } \\
& $\begin{array}{l}\text { 4.15 Designing bevel gear } \\
\text { 4.16 Determine the manufacture } \\
\text { of bevel gear }\end{array}$ \\
Machine & 4.17 Designing the manufacture \\
Techniques & $\begin{array}{l}\text { using a rotary table. } \\
4.18 \text { Determine the making of } \\
\\
\text { circular groove using rotary table }\end{array}$ \\
\hline
\end{tabular}

In order for VHS graduates to be employed, they must have those competencies needed by the industry. VHS graduates are potentials human resources who will work in the industrial world. VHS graduates are human-resource inputs for partner industries that must have mutually beneficial relationships with partner industries through increasing practical training activities such as the utilization of every resource owned by VHS and industries to increase students' competency to match the industry needs. Various activities are needed, including the use of shared equipment, expert exchanges and placement of students and teachers in the industry to make them experience the work culture in the partner industry (Raihan, 2014).

However, student activities in participating in learning still tend to be less. The value of low students has a dependence on other students who are high achievers and have high grades in working on problems and projects. In addition, there is also a lack of positive collaboration between students in an effort to master the material taught by the teacher.

The condition of learning also shows the low awareness of high achieving students towards friends who need help in understanding the subject matter. Based on observations, the researchers saw that class XII students were not independent in participating in learning because there was no desire to ask teachers or friends when there was a subject matter that was not understood. Thus, the learning outcomes of the milling machine techniques were also not satisfactory.

For this reason, improving student learning outcomes requires the application of a learning model that is in accordance with the learning experience expected by students. The success or failure of education depends on the teaching and learning process determined in choosing and applying the appropriate learning model (Suswanto et al., 2017). The effort that can be done to improve student learning outcomes is by industrial project-based learning. The benefits of collaborative project learning force students to work together to solve complex problems and technological developments and encourage students to think critically (Mitchell, Petter, \& Harris, 2017).

One of the well-known learning models is project-based learning. Project-based learning is a learning approach that considers the project as part of the infrastructure - projects in the form of thought, imaging, and function. Based on thinking, imaging, and function, it is to train the creativity of individuals who are responsible for their own learning outcomes (Yalçin, Turgut, \& Büyükkasap, 2009). The 
factory learning process can be designed with a focus on relevant competencies to develop competencies (Müller-Frommeyer, Aymans, Bargmann, Kauffeld, \& Herrmann, 2017).

Project-based learning model is quite useful in designing effective learning so that there is enough potential to meet the demands of learning (Sastrika, Sadia, \& Muderawan, 2013). Project-Based Learning (PBL) is an innovative approach to learning that teachers many important strategies for success in the 21st century (Bell, 2010). Project-based learning has the advantage of making learning stand out among other pedagogies, including involving students, improving cooperative learning skills, improving academic performance, developing higher-order thinking skills, and building positive relationships between students and teachers (See, Rashid, \& Bakar, 2015; Thomas, Mergendoller, \& Michaleson, 2000). Project-based learning as science-based learning has several fundamental features, which in the current learning process can go through several stages starting from the stage of asking, appreciating, analyzing, associating and concluding (Short, Lundsgaard, \& Krajcik, 2008).

Project-based learning generally has the steps of Planning (planning), Creating (implementation), and Processing. Project-based learning can help students in group learning, develop skills and the projects that are done are capable of providing a personal experience to students and can emphasize student-centered learning activities (Wena, 2008). Based on the statements above, the researchers conclude that industrial project-based learning is learning planned by teachers and industry, implemented into study groups so that they have almost the same environment as in the industry so that students can improve their skills.

However, the learning process is still conventional. It causes student learning motivation is still low. The data showed that in the pre-cycle, only $55.88 \%$ or 19 students passed the Minimum Completeness Criteria (Kriteria Ketuntasan Minimal or KKM). For this reason, it is necessary to improve student learning outcomes. Based on the previous description, the researchers were motivated to conduct research to improve the results of motivation and learning outcomes of students in industrial projectbased class XII in Milling Machine Engineering Subjects at SMK N 1 Semarang.

\section{RESEARCH METHOD}

This research was conducted at SMK N 1 Semarang (Semarang 1 Vocational School). The subjects of this study were 34 students of class XII of Mechanical Engineering. The classroom action research (CAR) method was chosen to improve the learning system, consisting of two cycles. The study was conducted from July to October 2018. This study was planned for two cycles, and reflection and evaluation were carried out in each cycle. The implementation of each cycle is shown in Table 2 . In carrying out the class actions research, each cycle includes stages which consist of: (1) planning, (2) implementation of actions, (3) observations, and (4) reflection.

In the planning stage, an industrial project-based learning strategy is formulated, namely compiling a Learning Implementation Plan. The implementation stage is to apply Industrial Project Based Learning (InPro-BL) in the classroom. This part is the most impor-

Table 2. Industrial Project Based Learning Implementation

\begin{tabular}{|c|c|c|c|c|}
\hline \multirow{2}{*}{ No } & \multicolumn{2}{|c|}{ Cycle I } & \multicolumn{2}{|c|}{ Cycle II } \\
\hline & Action & Outcome & Action & Outcome \\
\hline 1 & $\begin{array}{l}\text { The teacher submits the } \\
\text { purpose of learning and } \\
\text { what motivates learning }\end{array}$ & - & $\begin{array}{l}\text { Plan corrective actions based } \\
\text { on problems and learning } \\
\text { outcomes in the cycle }\end{array}$ & $\begin{array}{l}\text { Cycle II learning } \\
\text { planning }\end{array}$ \\
\hline 2 & $\begin{array}{l}\text { Students are divided into } \\
6 \text { groups of } 5-6 \text { students }\end{array}$ & Study groups & $\begin{array}{l}\text { Application of industrial } \\
\text { projects }\end{array}$ & - \\
\hline 3 & $\begin{array}{l}\text { Application of industrial } \\
\text { projects }\end{array}$ & product & $\begin{array}{l}\text { Evaluation of cycle II } \\
\text { learning outcomes }\end{array}$ & $\begin{array}{l}\text { Student learning } \\
\text { outcomes of cycle II }\end{array}$ \\
\hline 4 & $\begin{array}{l}\text { Evaluation of cycle I } \\
\text { learning outcomes }\end{array}$ & $\begin{array}{l}\text { Student learning } \\
\text { outcomes cycle } 1\end{array}$ & $\begin{array}{lll}\text { Overall } & \text { reflection } & \text { on } \\
\text { learning } & & \end{array}$ & $\begin{array}{l}\text { Improving student } \\
\text { learning outcomes }\end{array}$ \\
\hline 5 & Cycle I reflection & & & \\
\hline
\end{tabular}


tant stage because it is an improvement activity in the learning process. In observation stage, the research team observes student activities during the learning process, both about attitudes and behavior during learning. Reflection stage is an activity of analyzing and synthesizing from the results of observations during the learning process takes place, and at this stage, an evaluation is also carried out to determine the progress of student learning outcomes both individually and in groups. Then, the learning outcomes obtained by students will be compared with the learning completeness criteria which have been made.

The instrument used in this study is a sheet of assessment of the practical ability to make bevel gear. Data collection techniques used were observation, practice tests, and interview tests. The data analysis technique used was descriptive quantitative and qualitative.

The indicator of success in CAR is being able to reach criteria of good, or minimum if $85 \%$ of students achieve the KKM in the learning process. The criteria for the effectiveness of project-based learning are shown in Table 3 .

Table 3.Category of Industrial Project-Based Learning Effectiveness

\begin{tabular}{lc}
\hline \multicolumn{1}{c}{ Category } & Score \\
\hline Very effective & $75-100$ \\
Effective & $50-74$ \\
Less Effective & $25-49$ \\
Not Effective & $0-24$ \\
\hline
\end{tabular}

\section{RESULTS AND DISCUSSION}

In Cycle I, the actions carried out at the planning stage are: (a) Planning the time of learning implementation, held on August 6 October 1, 2018; (b) Preparing the location for the practice of Milling Machine Engineering, namely in the machining workshop of SMK N 1 Semarang; (c) Preparing material, media, and tools used for learning. The material taught is the basic competency in determining work requirements and focusing by using all machine tools on the competency standard to do work with a milling machine; (d) Preparing a set of learning implementation plans for the Milling Machine Engineering subject.

At this stage, some activities are carried out as planned. The implementation phase in the industrial project-based learning includes: (1) Preliminary stage, including (a) The teacher opens the lesson with opening activities; (b) The teacher conveys the learning objectives to be implemented; (c) The teacher conveys the outline of the subject matter to students. (2) Learning stage, including (a) Students arrange the work steps with the theme of the project to be carried out. The preparation of work steps focuses on the preparation of tools and materials to be used; (b) Students discuss with the teacher about the work steps prepared for the project work; (c) Students follow an evaluation. In this stage, students carry out project activities in accordance with the design made, results and assessment for reports, product assessment, and assessment. (3) Closing stage, in which the teacher invites students to conclude the learning outcomes together.

The implementation of Cycle I in learning using InPro-BL models on milling machine competencies shows that the increase of percentage in Minimum Completion Criteria at $55.88 \%$ increases $31.57 \%$ after Cycle I with a KKM of $73.52 \%$. The milling machining competency learning outcomes of Pre-cycle and Cycle I are shown in Table 4.

Table 4. Student Learning Outcomes of PreCycle and Cycle I

\begin{tabular}{clcc}
\hline No & Learning Score & Pre-Cycle & Cycle I \\
\hline 1 & Highest Score & 85 & 92 \\
2 & Lowest Score & 45 & 47 \\
3 & Average score & 73.32 & 81.23 \\
4 & Learning & $\mathbf{5 5 . 8 8}$ & $\mathbf{7 3 . 5 2}$ \\
& Completion $(\%)$ & & \\
\hline
\end{tabular}

There is an increase in pre-cycle student learning outcomes, and after Cycle I. Comparison of the average value of student learning outcomes before and after the first cycle can be seen in Figure 1.

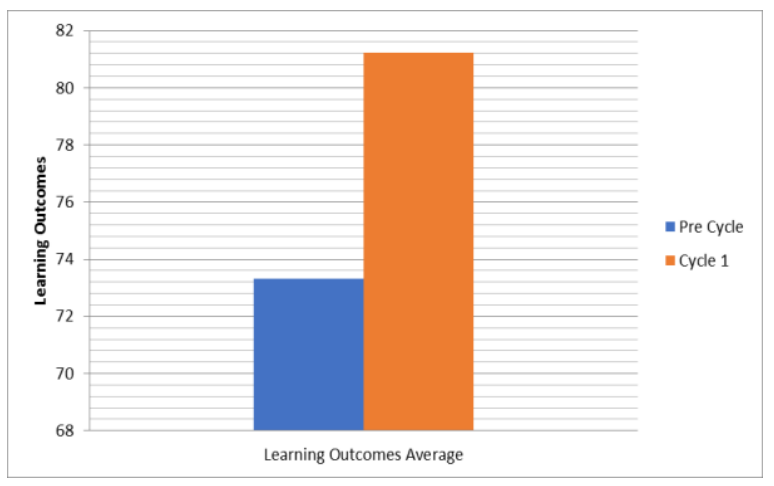

Figure 1. Student Learning Outcomes in PreCycle and Cycle I 
There is an increase in student learning outcomes after Cycle I. Students' average score increases from 73.32 to 81.23 . The percentage of classical learning completeness increases from $55.88 \%$ to $73.52 \%$. The number of students who experience an increase in grades is as many as 25 students. Learning outcomes have increased but have not achieved the class success of $85 \%$. Furthermore, the grouping of completeness values is based on the Reference Value Approach. The grouping of achievement of competencies can be seen in Table 5 .

Table 5.Comparison of Students Achievement Outcomes in the Pre-Cycle and After Cycle I

\begin{tabular}{cccc}
\hline No & $\begin{array}{c}\text { Learning } \\
\text { Score }\end{array}$ & $\begin{array}{c}\text { Pre-Cycle 1 } \\
(\boldsymbol{\%})\end{array}$ & $\begin{array}{c}\text { Cycle I } \\
(\boldsymbol{\%})\end{array}$ \\
\hline 1 & Very Good & 00.00 & 29.41 \\
2 & Good & 47.05 & 44.14 \\
3 & Less Good & 29.41 & 14.70 \\
4 & Not Good & 20.58 & 11.76 \\
\hline
\end{tabular}

Table 5 shows that $47.05 \%$ of students have competencies classified as good from the total students, the rest $29.41 \%$ are less good, and $20.58 \%$ is very poor. After Cycle I, there was an increase in student learning outcomes, namely students with very good competencies to be $29.41 \%, 44.14 \%$ is good, $14.70 \%$ is sufficient, and $11.76 \%$ is very less good competence, and reduce the less or very less.

The actions taken at the observation stage are recording the students' behavior and response to the learning carried out. Researchers observe the course of learning, along with peer teachers and industry observers. Field notes are used to record the subjects' behavior patterns in one cycle, from meeting 1 to meeting 2. The observers' task is to observe the course of the teaching and learning process as a whole. The observation sheet is used to record the behavior of each student in the group.

From the observations of the students, the following findings are obtained: (a) There are still many students who are quiet and less active and lacking in communication, although there are also students who are very active in communicating and asking about jobs to be done; (b) Still lacking in confidence in the work; (c) Steps to work and use of tools in some students is still inappropriate; (d) implementations of occupational health and safety is not good.
These results indicate that in the implementation of Cycle I, the majority of students have learning behaviors that are classified as less active and lacking in confidence. Students are still very dependent on the teacher in carrying out the work. Therefore, it is necessary to carry out the next cycle in order to determine the increase in student responses to learning activities. After observing the actions of learning in the classroom, a reflection on all activities that have been carried out in Cycle I was obtained.

Based on the results of reflection in the first cycle, the planning prepared for the second cycle was carried out by taking into account the following matters: (a) Teachers and industry guest must always encourage students to be active in carrying out the work; (b) The teacher also emphasizes that students are more courageous in carrying out work or expressing opinions and asking questions about the work steps, and the teacher must not laugh or be angry in giving the feedback, even the teacher must be proud of the students' courage; (c) To improve collaboration between students, on the next meeting, students are given time and opportunities to communicate with each other in a longer time; (d) The teacher reminds students that in carrying out work, students may use modules, handbooks, and other learning resources related to the learning material provided from the industry.

The learning implementation in Cycle II is to correct the shortcomings or problems that are faced in Cycle I. In Cycle II, meeting learning activities are still carried out with an industry project-based learning model. The steps taken at this meeting are still the same as the steps taken in Cycle I. However, this meeting was conducted with different material. The teacher reminds students to make the best use of time because the material being studied is quite a lot, and students may discuss with their friends.

The implementation of Cycle II in learning using industrial project-based learning (InPro-BL) models on milling machining competencies shows an increase in the percentage of KKM in the first cycle of $73.52 \%$ experiencing an increase of $20.01 \%$ after the second cycle, with a minimum completeness criteria of $88.23 \%$. The learning outcomes for Cycle I and Cycle II of machining competence are shown in Table 6. 
Table 6.Student Learning Outcomes in Cycle I and Cycle II

\begin{tabular}{llcc}
\hline No & Learning Score & Cycle I & Cycle II \\
\hline 1 & Highest Score & 92 & 95 \\
2 & Lowest Score & 47 & 70 \\
3 & Average & 81.23 & 86.32 \\
4 & Learning & $\mathbf{7 3 . 5 2}$ & $\mathbf{8 8 . 2 3}$ \\
& Completion (\%) & & \\
\hline
\end{tabular}

There is an increase in student learning outcomes in Cycle I and Cycle II. Comparison of the average value of student learning outcomes before and after the first cycle can be seen in Figure 2.

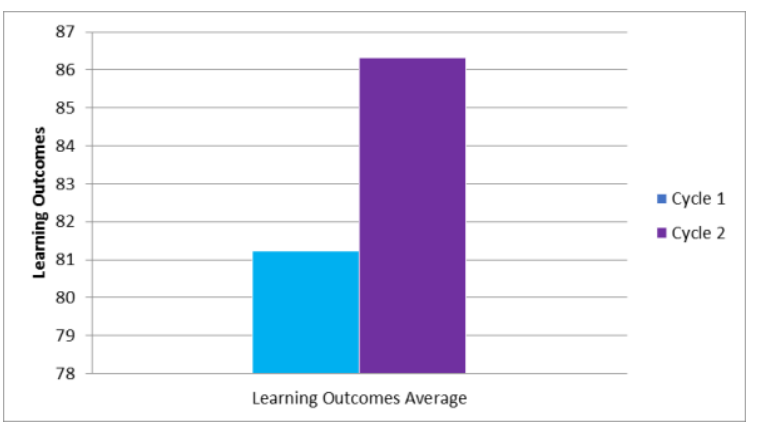

Figure 2. Student Learning Outcomes in Cycle I and Cycle II

The improvement of student learning outcomes after Cycle I is as follows. Students' average value increases from 81.23 to 86.32 . The percentage of classical learning completeness increases from $73.52 \%$ to $88.23 \%$. In the second cycle, the number of students with a return value increases by as many as 30 students. From these results, it can be seen that learning outcomes have increased and have succeeded in achieving the class success of $85 \%$. Furthermore, the disclosure of the results of the second cycle is based on Benchmark Reference Value. The grouping of competency achievements can be seen in Table 7 .

Table 7. Comparison of Student Competency Achievements Cycle I and Cycle II

\begin{tabular}{llcc}
\hline No & Learning Outcome & Cycle I & Cycle II \\
\hline 1 & Very good & 29.41 & 35.29 \\
2 & Good & 44.14 & 50.00 \\
3 & Bad & 14.70 & 11.76 \\
4 & Very Bad & 11.76 & 00.00 \\
\hline
\end{tabular}

In the first cycle, student learning outcomes have not met the established indicators, so it needs to be continued with the second cycle so that the predetermined indicators can be fulfilled. In the second cycle, there are no significant obstacles. Improvement of learning outcomes in Cycle II is caused by students who are familiar with the learning model applied by the teacher. The courage of students is growing so that their activeness also increases. It is indicated by the number of students who take advantage of the opportunity to answer questions, as well as express their opinions regarding the execution of material given by the teacher in the second cycle. Industrial projectbased learning makes students trained to carry out work independently and respect the workings of others and become more active in the learning process. The description above shows that the use of a project-based learning model on learning milling machines of class XII students of SMK N 1 Semarang can improve student learning outcomes at least $85 \%$ of students obtain a value $=75$.

Based on the data of the test results on the cycle above, completeness has not been achieved. Learning completeness obtained in the second cycle was $88.23 \%$ with an average value of 86.32 . The lowest value is 70 , and the highest value is 95 . It shows a change in a better direction and has been as expected because the results are expected to have achieved the expected classical completeness, namely $=$ $85 \%$. Based on the results of the research from pre cyclical to cycle II, there was an increase in learning in class XII students on Milling Machine subjects, the percentage of graduation before using InPro-BL is $55.88 \%$ and after learning the InPro-PBL method increases to $88.23 \%$. With an increase of $57.89 \%$, it shows that an effective industrial project-based learning model is able to develop student competencies that have an impact on improving student learning experiences and outcomes.

In Cycle II, the steps were taken as steps taken in Cycle I. The actions taken at the stage of observation are recording the behavior and response of students to the learning carried out. The researchers observed the learning process and the teacher and observer colleagues.

From the observations of students in Cycle II, the following findings are obtained: (a) Students have dared to answer teacher and industry guest questions, express opinions, and be more active in communicating with friends and teachers; (b) The classroom atmosphere is very controlled when learning activity takes 
place; (c) The work steps for all students are good; (d) Students have dared to answer the teacher's questions or their friends' questions. In addition, students have also shown courage in carrying out the work; (e) The use of tools by all students is good; (f) Occupational Safety and Health is well implemented.

Comparison of student learning outcomes in the Pre-Cycle, Cycle I, and Cycle II on students who achieved KKM is shown in Figure 3. Based on Figure 3, there is an increase before industrial project-based learning and after using industrial project-based learning.

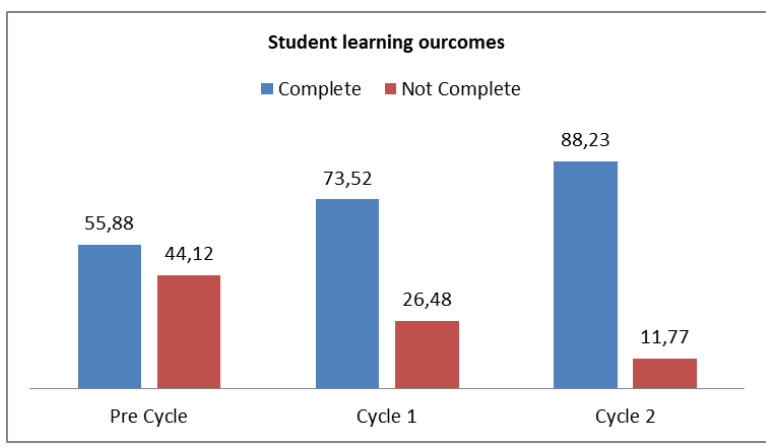

Figure 3. Comparison of Student Learning Outcomes in the Pre-Cycle, Cycle I, and Cycle II

Student experience and learning outcomes can be improved by paying attention to the management of learning time through the block system, teacher understanding in the industrial-based project learning, and mentoring industry guest teachers every learning process. Effective supervision of teachers in project learning influences student competence (Sadrina, Mustapha, \& Ichsan, 2018). Teachers also need to develop an understanding of industrial project-based learning to build confidence in developing student competencies.

\section{CONCLUSION}

The research results show that industrial project-based learning is effective in increasing the experience and results of the students learning outcomes of milling machines techniques at SMKN 1 Semarang. In Cycle I, there is an increase in learning outcomes, from 19 students who completed the KKM to 25 students or $73.52 \%$. In Cycle 2, there are $88.23 \%$ of students passed the KKM. Student experience and learning outcomes can be improved by paying attention to the management of learning time through the block system and industry guest teachers mentoring every learning process.

\section{ACKNOWLEDGMENT}

The researchers would like to thank Universitas Negeri Semarang for facilitating the research through the "Assignment of Lecturers at School (Penugasan Dosen di Sekolah or PDS)" program, and SMK 1 Semarang to provide opportunities in collecting the research data.

\section{REFERENCES}

Bell, S. (2010). Project-based learning for the 21st century: Skills for the future. The Clearing House: A Journal of Educational Strategies, Issues and Ideas, 83(2), 39-43. https://doi.org/ $10.1080 / 00098650903505415$

Bukit, M. (2014). Strategi dan inovasi pendidikan kejuruan: Dari kompetensi ke kompetisi. Bandung: Alfabeta.

Cheng, Y. C. (2005). New paradigm for reengineering education: Globalization, localization and individualization. Dordrecht: Springer Netherlands. https://doi.org/10.1007/1-4020-3620-5

Chiang, C. L., \& Lee, H. (2016). The effect of project-based learning on learning motivation and problem-solving ability of vocational high school students. International Journal of Information and Education Technology, 6(9), 709712. https://doi.org/10.7763/IJIET.2016 .V6.779

Ganefri, G. (2013). The development of production-based learning approach to entrepreneurial spirit for engineering students. Asian Social Science, 9(12), 162-167. https://doi.org/10.5539/ass.v9 n12p162

Gonczi, A. (2004). The new professional and vocational education. Crows Nest: Allen and Unwin.

Hamalik, O. (1983). Metoda belajar dan kesulitan-kesulitan belajar. Bandung: Tarsito. 
Kaslow, N. J., Bebeau, M. J., Lichtenberg, J. W., Portnoy, S. M., Rubin, N. J., Leigh, I. W., ... Smith, I. L. (2007). Guiding principles and recommendations for the assessment of competence. Professional Psychology: Research and Practice, 38(5), 441-451. https://doi.org/ 10.1037/0735-7028.38.5.44

Mitchell, A., Petter, S., \& Harris, A. L. (2017). Learning by doing: Twenty successful active learning exercises for information systems courses. Journal of Information Technology Education: Innovations in Practice, 16, 21-46.

Müller-Frommeyer, L. C., Aymans, S. C., Bargmann, C., Kauffeld, S., \& Herrmann, C. (2017). Introducing competency models as a tool for holistic competency development in learning factories: Challenges, example and future application. Procedia Manufacturing, 9, 307-314. https://doi. org/10.1016/J.PROMFG.2017.04.015

Prosser, C. A., \& Allen, C. R. (1959). Vocational education in a democracy. Chicago, IL: American Technical Society.

Raihan, M. A. (2014). Collaboration between TVET institutions and industries in Bangladesh to enhance employability skills. International Journal of Engineering and Technical Research (IJETR), 2(10), 50-55.

Rentzos, L., Doukas, M., Mavrikios, D., Mourtzis, D., \& Chryssolouris, G. (2014). Integrating manufacturing education with industrial practice using teaching factory paradigm: A construction equipment application. Procedia CIRP, 17, 189-194. https:// doi.org/10.1016/J.PROCIR.2014.01.12 6

Ryan, R. M., \& Deci, E. L. (2000). Intrinsic and extrinsic motivations: Classic definitions and new directions. Contemporary Educational Psychology, 25(1), 54-67. https://doi.org/ 10.1006/CEPS.1999.1020

Sadrina, S., Mustapha, R., \& Ichsan, M. (2018). The evaluation of project-based learning in Malaysia: Propose a new framework for polytechnics system. Jurnal Pendidikan Vokasi, 8(2), 143150. https://doi.org/10.21831/jpv.v8i2. 19100

Sastrika, I. A. K., Sadia, W., \& Muderawan, I. W. (2013). Pengaruh model pembelajaran berbasis proyek terhadap pemahaman konsep kimia dan keterampilan berpikir kritis. Jurnal Pendidikan Dan Pembelajaran IPA Indonesia, 3(2), 1-10. Retrieved from http://oldpasca.undiksha.ac.id/e-journal/ index.php/jurnal_ipa/article/view/799

See, Y. G., Rashid, A. M., \& Bakar, A. R. (2015). The effect of project based learning on level of content knowledge of pre-vocational subject. Mediterranean Journal of Social Sciences, 6(6 S4), 369-375. https://doi. org/10.5901/mjss.2015.v6n6s4p369

Short, H., Lundsgaard, M. F. V., \& Krajcik, J. S. (2008). How do geckos stick? Using phenomena to frame project-based science in chemistry classes. The Science Teacher, 75(8), 38-49. Retrieved from https://www.questia. com/library/journal/1G1-191011805/ how-do-geckos-stick-using-phenomena -to-frame-project-based

Sumbodo, W., Pardjono, Samsudi, \& Rahadjo, W. D. (2018). Implementation of partnership management model of SMK (Vocational High School) with existing industries in mechanical engineering expertise in Central Java. In AIP Conference Proceedings (Vol. 1941, p. 020038). https://doi.org/10.1063/1.502 8096

Suswanto, H., Hamdan, A., Mariana, R. R., Dardiri, A., Wibawa, A. P., Nafalski, A., \& Vianiryzki, A. F. (2017). The effectiveness of project-based learning and STAD learning on improving Web programming competency. World Transactions on Engineering and Technology Education, 15(4), 368-373.

Thomas, H. W., Mergendoller, J. R., \& Michaleson, A. (2000). Projects based learning: A handbook for middle and high school teachers. Navato, CA: The Buck Institute for Education. 
Wena, M. (2008). Strategi pembelajaran inovatif kontemporer. Malang: Bumi Antariksa.

Yalçin, S. A., Turgut, Ü., \& Büyükkasap, E. (2009). The effect of project based learning on science undergraduates' learning of electricity, attitude towards physics and scientific process skills. International Online Journal of Educational Sciences, 1(1), 81-105.

Yudiono, H. (2017). The alignment of productive competence on machinery between vocational education institutions and industry. World
Transactions on Engineering and Technology Education, 15(3), 256-259. Retrieved from http://www.wiete.com. au/journals/WTE\&TE/Pages/Vol.15, No.3 (2017)/10-Yudiono-H.pdf

Yudiono, H., Soesanto, S., \& Haryono, H. (2018). An industrial competency-based curriculum alignment model. World Transactions on Engineering and Technology Education, 16(1), 18-22. Retrieved from http://www.wiete.com. au/journals/WTE\&TE/Pages/Vol.16, No.1 (2018)/03-Yudiono-H.pdf 